\title{
Playful pedagogy for deeper learning: exploring the implementation of the play based Foundation Phase in Wales.
}

\section{Early Child Development and Care}

Received 01 Sep 2018, Accepted 01 Dec 2018, Published online: 18 Sep 2019

Nalda Wainwright, Jackie Goodway, Margaret Whitehead, Andy Williams, David Kirk

Wales Institute for Physical Literacy, University of Wales Trinity Saint David, Carmarthen, UK; Department of

Human Sciences, The Ohio State University, Columbus, OH, USA; University of Bedfordshire, Bedford, UK; School

of Sport Health and Outdoor Education, University of Wales Trinity Saint David, Carmarthen, UK; School of

Education, University of Strathclyde, Glasgow, UK

N.wainwright@uwtsd.ac.uk

https://doi.org/10.1080/03004430.2019.1653551 


\section{Playful pedagogy for deeper learning : exploring the implementation of the play based Foundation Phase in Wales.}

The foundation phase in Wales is a play based curriculum for $3-7$ year olds advocating the use of the outdoors and experiential approaches to learning (DCELLS, 2015). Play based outdoor learning increases interaction with a range of affordances giving opportunities for movement in learning. Children assign activities as either play or not play based on a series of cues (Howard, 2002). Teaching approaches that incorporate cues associated with play can influence pupil engagement and involvement in learning. This paper draws on data from a three year study of the implementation of the foundation phase. Analysis of data from observations, field notes and video suggest pupils were more involved in tasks with higher levels of well-being when tasks were perceived as play. Leavres $(1993,1997,2000,2005)$ suggests increased involvement in learning may result in deeper learning.

Keywords: play; outdoor learning: pupil engagement

Subject classification codes: include these here if the journal requires them

\section{Introduction}

The Foundation Phase in Wales is a play-based curriculum for 3- 7 year olds similar to a growing international trend that sees a move from traditional subjects to more authentic areas of learning (DCELLS, 2015). The Welsh Government highlights the importance of play in the Foundation Phase as a way 'children become self-aware,' 'learn social rules' as well as being 'fundamental to intellectual development' (DCELLS, 2015:6). Existing literature has sought to examine the pedagogical role of adults in children's play (Fleer, 2015), interpretation of tasks as play (Howard, 2002; Howard et al., 2002; Howard and McInnes, 2013) and children's perspectives on play 
and learning (Pyle and Alaca, 2018).

To contribute to this discourse, this paper presents findings from part of a study that sought to explore the interpretation and delivery of the Foundation Phase in Wales. The paper firstly examines experiential learning in relation to the Foundation Phase as a play based curriculum, in particular it focuses on the relationship between play, affordances, motivation and engagement in learning and how this relates to children's perceptions of a task. Drawing on the findings from the study and existing literature, this paper suggests that by using experiential approaches to learning pupils are more likely to interpret tasks as play and as such have greater engagement and deeper involvement in the learning.

\section{The Foundation Phase, experiential learning and play}

The Foundation Phase framework advocates an experiential, play-based approach to learning in which practitioner-directed activities are balanced with those initiated by children and the outdoor environment is an integral part of the children's learning and experience (DCELLS, 2015; Maynard et al., 2011; Wainwright et al., 2016). The Foundation Phase framework identifies seven areas of learning which are not approached in isolation but form part of a holistic, integrated and cross-curricular approach with an emphasis on the development of skills (WAG, 2007:6). The seven areas of learning are:

- Personal and Social Development, Well-Being and Cultural Diversity

- Language, Literacy and Communication Skills

- Mathematical Development

- Welsh Language Development

- Knowledge and Understanding of the World 
- Physical Development

- Creative Development.

(DCELLS, 2008:2)

This approach means that subjects in their traditional form no longer exist, such as the subject of Science which would now be covered in the area of Knowledge and Understanding of the World. During the conceptualization of the Foundation Phase, ministers observed curriculum models, which have influenced educational practice and approaches internationally such as High-Scope, Reggio Emilia, and Te Whāriki. These are all open curricular approaches and as such emphasise active participatory learning, interaction, reasoning, reflection and responsibility for self-learning (Anning and Edwards, 1999; Epstein, 2013). These approaches are reflected in Government documentation which advocates an approach where 'children learn through first-hand experiential activities with the serious business of 'play' providing the vehicle' (DCELLS, 2015:4). As a play-based curriculum the interpretation of play in the Foundation Phase is not clearly defined and perhaps most useful for the context of the Foundation Phase as a play based curriculum is Pelegrini's (1991: 215) notion of a continuum suggesting 'acts should not be categorised as 'play' or 'not play': they should be related along a continuum from 'pure play' to 'non play'. This idea of a continuum has also been advocated more recently by Pyle and Danniels (2017) and works well for the Foundation Phase where children move from adult-led activities to more freely chosen tasks and even many of the teacher-led tasks are playful in their nature. Wood and Attfield (2005:5) maintain the challenge of defining play is because 'play is always context dependent'. Dewey's work of the 1930s highlighted the importance of context in relation to experience and the important responsibility of 
educators to recognise surroundings that 'are conducive to having experiences that lead to growth' (1938: 40).

The environment is an important factor in relation to engagement in learning where in order for motivation, development and performance to be maximised, the social context needs to satisfy the 'basic psychological needs for competence, relatedness, and autonomy' (Deci et al., 1991:327). Autonomy supportive teachers induce greater intrinsic motivation, curiosity and a desire for challenge, whilst students who are overly controlled lose initiative and learn less well (Benware and Deci, 1984; Ryan and Deci, 2000; Ryan and Grolnick, 1986). Motivation is strongly related to engagement as Reeve et al. (2004:147) explain when they describe engagement as 'the behavioural intensity and emotional quality of a person's active involvement during a task' highlighting its 'many interrelated expressions of motivation, such as intrinsically motivated behaviour, self-determined extrinsic motivation, work orientation and mastery motivation. Engagement can be described as the level of participation and intrinsic motivation that a pupil shows in their task, and is a combination of behaviours such as persistence, effort and attention and attitudes such as motivation, interest, enthusiasm, positive learning values and pride in success (Akey, 2006; Laevers, 1993; Newmann, 1992). A growing body of research suggests engagement is associated with achievement in standardised tests and more favourable lifelong outcomes (Marks, 2000; Taylor and Nelms, 2006). Reeve (2006:225) claims that 'students' classroom engagement depends in part on the supportive quality of the classroom climate in which they learn' and that 'teachers most engage students when they offer high levels of both autonomy support and structure.' This is of particular relevance to the Foundation Phase 
with its combination of adult-led and child-initiated learning, which according to Reeve (2006), should result in high levels of student engagement.

Csikszentmihalyi's concept of 'flow' $(1979,1989)$ has often been linked to engagement in a task (Harmer and Cates, 2004; Laevers, 1994). The concept of 'flow' develops an understanding of 'experiences during which individuals are fully involved in the present moment' (Nakamura and Csikszentmihalyi, 2002:89). Nakamura and Csikszentmihalyi (2002:90) explain how individuals in a state of flow describe how 'an experience seamlessly enfolds from minute to minute' and identify characteristics of the state as 'intense and focused concentration on what one is doing in the present moment.' Akey (2006) suggests being in a state of flow indicates enjoyment of learning. Laevers (1994) in his theory of experiential education explains how deep immersion in learning has an affective component, and he recognises the combination of behavioural and affective components as involvement and well-being. Laevers (1997:2) suggests that involvement is seen as an indication for changes that are defined as 'deep level learning' (Laevers, 1997:2) and in order to gain an insight into high quality learning environments developed the Leuven Involvement and Well-Being Scale (Laevers, 1994). Subsequent studies have shown pupils' involvement is dependent on the 'interactions between the context (including the way teachers handle their group) and the characteristics of the children' (Laevers, 2000:25). Large studies of effective early learning with 60,000 pre-primary age children show that the more competent the teacher, the higher the level of involvement and well-being (Laevers, 2011; Laevers et al., 2005; Pascal and Bertram, 1995; Pascal et al., 1998) implying teacher competence is synonymous with promoting autonomous behaviours and decision-making in children. Laevers (2000:25) however cautions that this state of involvement is not easily obtained as it 'only occurs in the small area in which the activity matches the capabilities of the 
person.' He suggests that 'young children usually find it in play' and it is in play that we see an 'exploratory attitude, defined by openness for, and alertness to, the wide variety of stimuli that form our surroundings'. This attitude enables a person to find 'the most intense forms of concentration and involvement' and it is this attitude underpinned by deep intrinsic motivation that keeps a person learning and developing (Laevers, 2000:25). The challenge for education is to keep this intrinsic source of motivation alive as a wealth of existing research shows that intrinsic motivation declines as children progress through the education system (Anderman and Maehr, 1994; Gottfried et al., 2001; Lepper et al., 2005; Nicholls, 1978;Opdenakker, Maulana and den Brok, 2012; Sansone and Morgan, 1992).

The links between play and high levels of involvement and intrinsic motivation have been well documented (Brock et al., 2009; Brooker and Edwards, 2010; Howard, 2002; Howard and McInnes, 2010, 2011; Moyles, 2010), however Wood and Attfield (2005:7) warn of 'the danger of overlooking the fact that children have their own definitions of play'. This is highlighted in the work of McInnes et al. (2011) who studied children's approaches to activities and proposed that children make their own distinctions between work and play. It is also useful to consider the internally driven affective quality of play that has such an important role in motivation and engagement (Moyles, 1989). Although Feezell (2013) and Dewey (1933) both acknowledged an attitudinal component in play, Dewey (1933:210) made a distinction between playfulness and play where "the former is an attitude of mind; the latter is an outward manifestation of this attitude'. Howard and McInnes (2010:34) highlight that playfulness implies freedom and flexibility and suggest that 'viewing playfulness, as an attitude of mind, rather than play, the outward act, may be the most helpful way yet of 
thinking about this elusive concept and of providing a theoretical basis for implanting a play-based curriculum' such as the Foundation Phase. They further propose that utilising a concept of play which is based on children's perceptions highlighting playfulness as an approach and attitude to an activity may help to develop practitioners understanding of play (Howard and McInnes, 2010).

Howard and McInnes's (2010:35) work highlights how children make the distinction between play and not play 'enabling them to map activities on a play-work continuum' (McInnes et al., 2011:123) with clear cues illustrated in Table 1.

Table 1. Cues that children use to distinguish between play and work

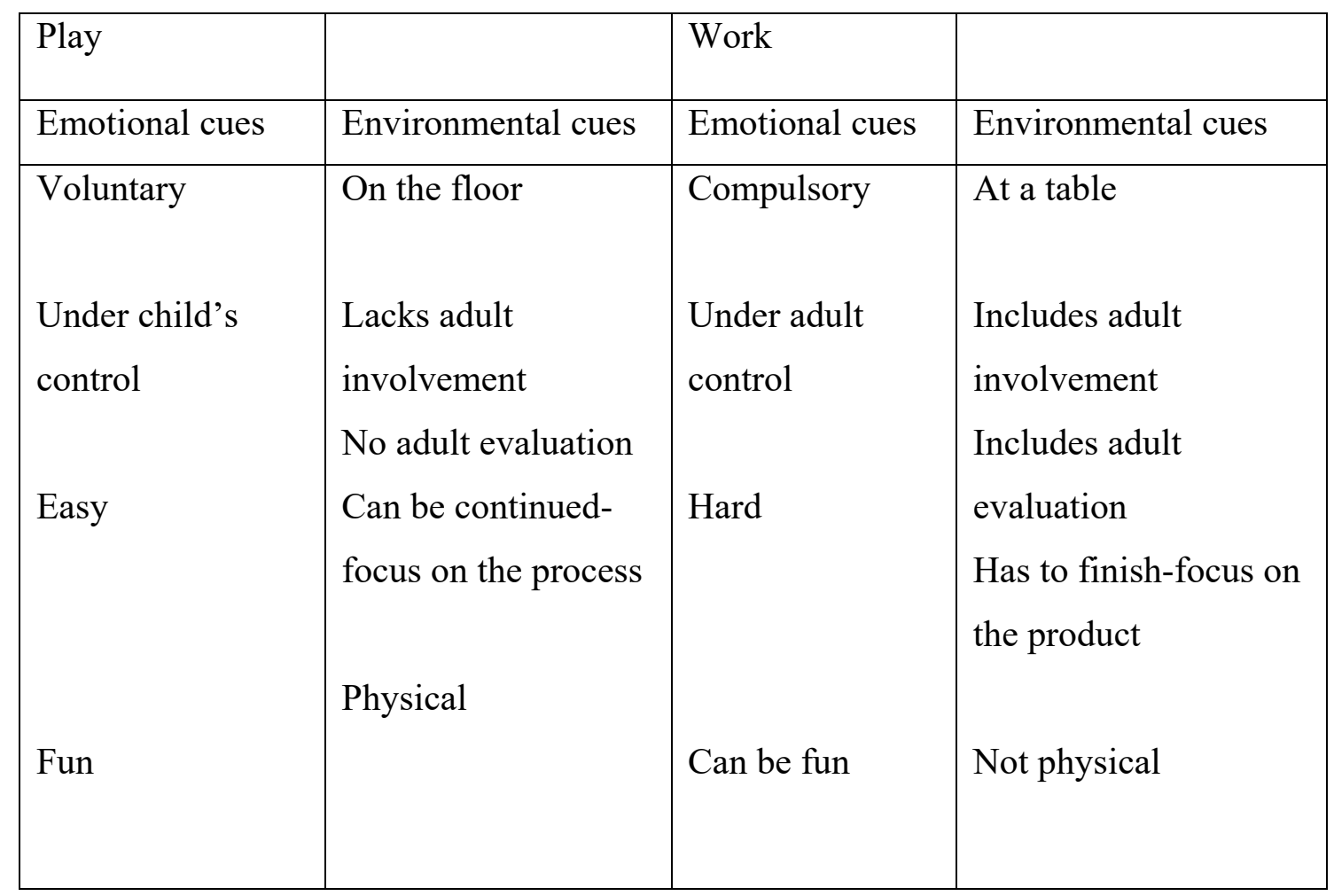

(Howard and McInnes, 2010:35)

This distinction that children make between play and work is of particular importance as 'children who practice a task under playful practice conditions (on the floor, adult nearby, choice) show superior performance and behaviours conducive to learning 
compared with children in a formal practice condition (at a table, adult present, no choice)' (McInnes et al., 2009:124). McInnes et al. (2009:122) propose from their research that it is not whether the activity is play or not that is the issue, but rather 'the playful approach and attitude that is taken to an activity'. This is highly relevant to the Foundation Phase, as teachers need to ensure pupils are learning in a structured environment and this will inevitably reduce the opportunities for 'pure play' as described in Pellegrini's (1991) continuum. Although the experiences in the Foundation Phase are in the main structured in the sense that they are conceived, designed and introduced by teachers, it is the ability of the children to make choices about how they engage with these experiences that allow them to conceive of their learning experiences as playful. This notion of playful practice allows children to learn in a way that they perceive as play, thus maintaining motivation and engagement in the task. It is clear in the table that choice and autonomy are cues, which children relate to play. As autonomy is strongly associated with intrinsic motivation this has clear implications for levels of motivation and engagement (Deci and Ryan, 1995; Niemiec and Ryan, 2009).

As shown in table one the cues children use are based on environmental factors such as location and the presence of an adult, and emotional factors such as choice of the activity. McInnes et al. (2011:123) suggest that it is the use of these cues that enables children to 'map activities on a play-work continuum'. McInnes et al. (2011) draw on Gibson's (1986) theory of affordances in their discussions relating to environmental cues whereas Fiskum and Jacobsen (2013:77) explain 'an affordance is an incentive to action'. Kytta (2002) and Fjortoft (2001) in studying affordances in children's environments identify how the physical environment offers different modes of play, such as space and smooth surfaces afford running and cycling, and trees afford 
climbing and swinging, whist shelters offer peace and quiet. The concept of affordances of the environment are of particular relevance as they suggest cues for children in relation to their activity. The environment can therefore be manipulated to form cues children use to define play and as such create playful conditions which 'impacts on performance, behaviour and learning' (McInnes et al., 2009, cited in McInnes et al., 2011:123; Radcliffe 2007; Thomas et al., 2006). Papatheodorou (2010:145) argues that spaces 'shape and condition how we feel, think and behave,' therefore by manipulating these cues practitioners can work to co-construct a learning environment that 'reduces the cue distinctions, blurs the boundaries between play and not play and engenders playfulness' (Howard and McInnes, 2010:37). Young children in action need spaces arranged and equipped to promote active learning and the Foundation Phase advocates a well-planned space to be a learning environment giving many opportunities for children to develop through both child-initiated and adult-led play activities (Hohmann et al., 2002; DCELLS, 2015). If, as evidence suggests, the organization of the whole school space, including the outdoor space as well as the classroom, the resources and the design of educational spaces, affect children's learning and how they perceive an activity, then the management of these spaces as well as the tasks is crucial to allowing children autonomy in their learning and creating an ethos of playfulness (Howard and McInnes, 2013; McInnes et al., 2011; Papatheodorou and Ramasult, 1994; Penrose et al., 2001).

\section{Study Design}

\section{Research question}

This paper reports on data from a large three phase complementarity mixed methods design which sought to understand the interpretation and implementation of the 
Foundation Phase in Wales. Part of this study, reported in this paper, sought to explore pupil engagement in learning. Specifically it asked what were the levels of pupils' involvement and engagement in activities in the Foundation Phase?

\section{Participants}

Two schools were selected for the study through 'reputational case sampling' (Teddlie and Tashakkori, 2009:74) on the basis of recognition of high quality Foundation Phase provision as identified by government school inspectors and advisors. The selection process involved ESTYN Inspection Reports, Local Authority Self Evaluation Reports, Higher Education Partnerships, and the acknowledgement from the wider professional community. School A was situated in a small rural village in West Wales. Pupils attended from a catchment area that was neither economically or socially disadvantaged. There were 143 pupils on roll taught in six classes. $18 \%$ of pupils had additional learning needs and approximately $7 \%$ of pupils were entitled to free schools meals. School B was situated in a large town in West Wales. Pupils attended from an urban catchment where approximately half of the school's intake came from economically disadvantaged areas. About $40 \%$ of the pupils were entitled to free school meals, which was much higher than the average for Wales (21\%). The school had 400 pupils on roll in fifteen mainstream classes and two special units that cater for pupils with complex needs. The school identified $34 \%$ of pupils as having additional learning needs, which is well above the average for primary schools $(22 \%)$. Both schools had large outdoor spaces for the pupils to access at playtime. A year one class (children aged five and six years old) from each school was selected for the study. The year one class in school A had twenty-three pupils (thirteen girls and ten boys) in total and the year one class in school B had twenty-six pupils (fourteen girls and twelve boys) in total 
$(N=49)$. The classrooms in both schools also opened into an outdoor learning area that was accessed during teaching times.

\section{Methodology}

The Foundation Phase as a 'naturalistic intervention' is multi-layered and complex (Cohen et al., 2008). In order to gain a deep understanding of the complexities of the curriculum the research required a mixed-methods pragmatist approach which combined methods from quantitative and qualitative paradigms in a complementarity mixed-method design. This enabled the study to measure overlapping but also different facets of children's learning. In order to answer the research question reported in this paper, quantitative and qualitative data were generated with the Leuven Involvement scale. Additional qualitative data were generated with field note observations and video.

The Leuven Involvement Scale for Young Children (LIS-YC) is part of the SiCs self-evaluation instrument and has been devised as an assessment tool for identifying deep level learning (Laevers, 1994). 'The concept of involvement represents one of the central axes in experiential theory' (Laevers 1997:4). Work by Laevers $(1993 ; 1994)$ to operationalize this notion resulted in the construction of the Leuven Involvement Scale (LIS). The Leuven Involvement Scale for young children (the LIS-YC) is a five-point scale and focuses on young children (three to six years.). During the rating process a series of signals are attended to: concentration, energy, complexity and creativity, facial expression and posture, persistence, precision, reaction time, verbal utterances and satisfaction (Laevers, 1997). The key aspect of the scale is the five levels of involvement. Level one means: no activity; Level two: frequently interrupted activity; Level three: more or less continuous activity; Level four: activity with intense moments, Level five: sustained intense activity (Laevers, 1994). The LIS-YC was used to observe 
the level of involvement and as such pupils' engagement in their learning during various tasks and activities in the Foundation Phase. The observations were carried out when the researcher saw an appropriate opportunity with pupils working in groups. There was no pre-determined time allocated for the observations. The observations were carried out as per the manual during activities that were 'the normal course of affairs' (Laevers et al., 2005:2). The group size observed ranged from three to nine pupils.

Throughout the study, field notes were written both in situ and also away from the situation. Immediacy in recording field notes helped to overcome problems of reliability whilst writing some field notes later helped to ensure there was 'a detailed record of both objective observations and subjective feelings' (Spradley, 1980:58) and maintain a high level of reflexivity. Pages and lines in the field note journals were numbered clearly in order to have a clear trail of all comments back to their source throughout the process of analysis with a total of 281 pages of field notes. Pseudonyms have been used for participants in the reporting of data to ensure anonymity.

Video recording was used to complement participant observations and field notes. For the purpose of this study the emphasis was on the use of video to capture the context of the Foundation Phase in particular when many different activities were happening. This allowed for field notes to still be written and be complemented by film footage. A total of eighty-nine videos were taken.

\section{Analysis}

Leuven Scale observations measured the levels of pupil engagement in learning giving a score for involvement. A chi-squared analysis was also undertaken to examine 
if engagement levels were different if the teacher selected the task or the child selected the task.

Qualitative data was analysed using the constant comparative method of inductive data analysis, first developed by Glaser and Strauss (1967) and drawn upon by Maykutt and Morehouse (1994). This process involved the identification of units of meaning within the data. These were compared to other units and where similarities occurred, grouped into clusters of relevant meaning. From these clusters of relevant meaning, categories and themes emerged. Videos were analysed through a similar process. Footage was coded and labelled into themes.

Mixed method research requires the analysis of data from multiple methods during the analysis stage and not just at the interpretation stage (Greene et al., 1989). Data Consolidation / Merging is the 'joint review of both data types to create new or consolidated variables or data sets' (Carnacelli and Greene, 1993:235). In the study, video footage was analysed alongside Leuven observations and field notes to create qualitative narratives for further analysis and interpretation.

\section{Limitations}

The sample of two classes from two schools in West Wales cannot be viewed as representative of Foundation Phase classes across Wales. Schools were selected on the basis of being recognised for their good practice in the implementation of the Foundation Phase in order to gain an understanding of the impact of the curriculum when implemented well. Data were generated over a year in the two schools with in depth analysis of multiple methods and as such does give some in depth insight into the experiences of the pupils and the playful pedagogical practices in the schools. However 
the findings reported in the following section should be considered with limitations of sample size in mind.

\section{Findings and discussion}

As might be expected in a play-based curriculum high levels of engagement were noted, in particular in choice activities and activities that children perceived as play. Table 2 shows the scores for observations using the Leuven Involvement Scale.

Table 2: Leuven Involvement scale

\begin{tabular}{|l|l|l|l|l|l|l|l|}
\hline & Total & $\begin{array}{l}\text { Score 5 } \\
\text { Extremely } \\
\text { high }\end{array}$ & $\begin{array}{l}\text { Score } \\
4 \\
\text { High }\end{array}$ & $\begin{array}{l}\text { Score 3 } \\
\text { Moderate }\end{array}$ & $\begin{array}{l}\text { Score } \\
2 \\
\text { Low }\end{array}$ & $\begin{array}{l}\text { Score 1 } \\
\text { Extremely } \\
\text { low }\end{array}$ & Mean score \\
\hline $\begin{array}{l}\text { No. of } \\
\text { obs }\end{array}$ & 56 & 17 & 16 & 14 & 8 & 1 & 3.7 \\
\hline$\%$ of obs & $100 \%$ & $30.4 \%$ & $28.6 \%$ & $25 \%$ & $14.3 \%$ & $1.8 \%$ & \\
\hline
\end{tabular}

The mean score of 3.7 indicates that children had high levels of involvement in their learning as can be seen in Table 3. 58.09\% of all the observations were scored in the high / very high category and only $16.1 \%$ were in the very low/ low category. These findings were high in relation to previous research where post-test scores after an intervention to improve involvement were 3.47 (Laevres et al., 2010).

Table 3: Percentage of observations in each category of the Leuven Involvement scale

\begin{tabular}{|l|c|c|c|}
\hline $\begin{array}{l}\text { Category of } \\
\text { involvement } \\
\text { score }\end{array}$ & $\begin{array}{c}\text { High / very high } \\
\text { engagement } \\
4 \text { and 5 }\end{array}$ & $\begin{array}{c}\text { Moderate } \\
\text { engagement }\end{array}$ & $\begin{array}{c}\text { Low / very low } \\
\text { engagement } \\
1 \text { and } 2\end{array}$ \\
\hline
\end{tabular}




\begin{tabular}{|l|c|c|c|}
\hline $\begin{array}{l}\text { Percentage of } \\
\text { observations }\end{array}$ & $59 \%$ & $25 \%$ & $16 \%$ \\
\hline
\end{tabular}

Part of the Leuven Involvement scale includes qualitative observations. These qualitative comments were also noted which recorded some of the behaviours that led to the scores. An example of qualitative comments from one observation are shown in Table 4.

Table 4: Qualitative Comments for a Leuven Involvement observation

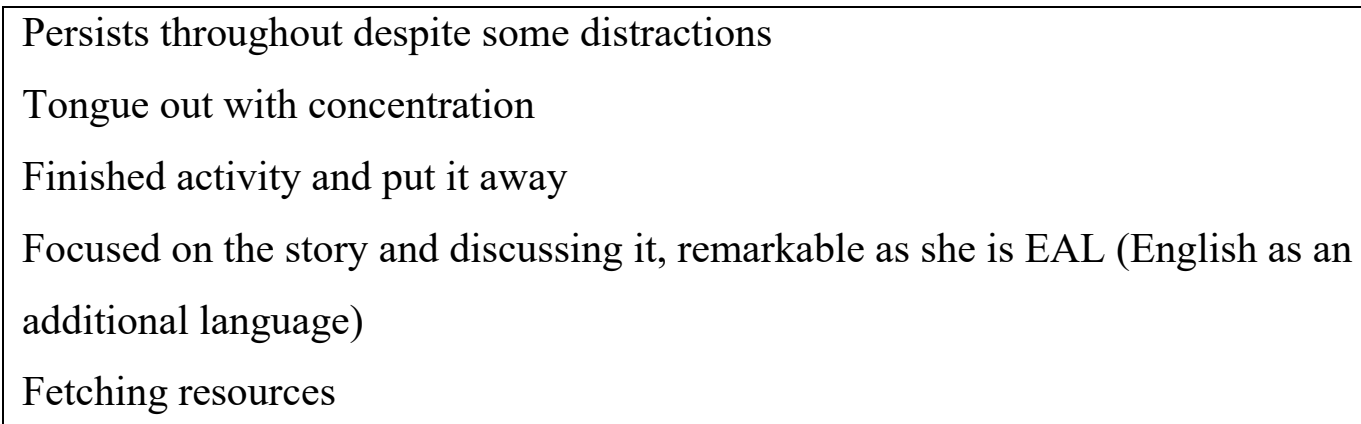

A Chi-squared analysis was undertaken to examine if engagement levels were different if the teacher selected the task or the child selected the task. The categories of very and low were combined and high and very high were combined in order to have large enough numbers of the Chi-squared analysis although two cells were still below 5 . The Chi-squared analysis found higher levels of engagement in tasks that the child selected with significance of $p=.021$. The data indicating higher levels of involvement when the task was chosen by the pupil and not teacher-directed are shown in table 5.

Table 5: Involvement scores percentage per category

\begin{tabular}{|l|c|c|c|c|}
\hline \multirow{2}{*}{ Task } & \multicolumn{3}{|c|}{ Involvement } & \multirow{2}{*}{ Total } \\
\cline { 2 - 3 } & Very low/ low & Moderate & High/very high & \\
& involvement & involvement & involvement & \\
\hline
\end{tabular}




\begin{tabular}{|l|c|c|c|c|}
\hline Directed & $24.1 \%$ & $34.5 \%$ & $41.4 \%$ & $100.0 \%$ \\
\hline Choice & $7.4 \%$ & $14.8 \%$ & $77.8 \%$ & $100.0 \%$ \\
\hline
\end{tabular}

This finding supports the previous findings of Deci and Ryan (1995) and Deci et al., (1994:123) who define autonomy support as valuing 'self-initiation', 'children's choice, independent problem solving, and participation in decision making', and is strongly associated with intrinsic motivation. Pupil choice, experimentation and selfinitiation are features of an autonomy supportive climate (Reeve and Jang, 2006; Hastie et al., 2013). The data from the Leuven Involvement scale observations supports this. Activities that were chosen by the children were seen to have higher levels of involvement in the task. Pupils were clearly more motivated and engaged when they had selected the task.

The findings from qualitative observations were analysed to complement the quantitative data. There were numerous examples from observations in field notes that commented on pupil engagement across a range of activities, 'Katy is involved in her Picasso portrait focused and getting on-continuing work she has already begun. The writing group also all engaged (Field notes p6, L10). As identified in the Leuven involvement observations high levels of engagement were particularly evident in child choice activities with field notes and video footage highlighting this 'children are all engaged and busy in a whole range of activities' (Field notes p90, L17; Video 4) and 'all children very focused on tasks and play (Field notes p91, L20). Reflections in field notes commented on how it was 'quite remarkable to see how busy, focused and engaged the children were during the free choice time (Field notes p92, L11). 
There were observed exceptions when pupils were 'all engaged except Jo who is day dreaming' (Field Notes p9,L1). 'Jim fussing with his knee' (Field notes p86, L13) 'Chris fidgets, moves from his place he is only child not focusing on the story' (Field notes p133, L5) 'Jim doesn't seem to be doing as he is supposed to - he lies on top of the sandpit!' (Field notes p161, L20).

Although there were exceptions, as the Leuven observation data and field notes show, the consistent theme with this play-based active approach was high levels of engagement by the majority of pupils most of the time. Although the data show that when teachers made the choice of activity the children were less engaged, the levels of engagement were still high with $76.9 \%$ of observations for the teacher-directed tasks still in the moderate to very high levels of engagement categories.

This high level of engagement even in teacher directed activities may have been related to the playful nature of the tasks. Despite being teacher-directed many activities included cues that children associate with play (Howard and McInnes, 2010). In particular tasks were often outside, fun and involved being able to move around during their activities. A particular example of this was during an outdoor session that included teacher-directed challenges. Children were able to choose from a variety of activities related to the theme of stones. One of the challenges was focussing on the area or learning of Knowledge and Understanding of the World and was called 'can you make a stone float?' Notes from video footage showed how the children engaged with the task 'the group have decided to make boats for the stones. They collect containers of different sizes and materials and try them out with small stones. One of them works and stays afloat. They are very excited and show the teacher. She asks them if it will move, 
so they blow it and it travels across the tough tray full of water without capsizing'

(Video 1). It is clear from the analysis of the video footage that the children were very focussed on the task and soon others come over to observe and join in. The role of the teacher in these choice sessions was that of facilitator and she continued to ask questions to challenge them 'do you think you can put more stones in there? Or a larger stone? The children who have just joined the group are excited, one jumps up and down and rushes to fetch more stones' (Video 1). The task and environment had many of the cues Howard and McInnes $(2010 ; 2013)$ suggest pupils identify as play such as outside, physical and fun. Also evident here was the 'children's willingness to engage with their teachers during playful activities' (Pyle and Alaca, 2018) which enabled the teacher to ensure appropriate learning for the pupils in the class. Despite the pupils in year one being aged only five and six years old, they remained engaged in the task of experimenting with making stones float for a sustained period of time clearly enjoying the task.

Another example which illustrated the integrated and cross curricular approach of the Foundation Phase was a literacy session in the woods that involved collecting and sorting natural materials to make a collage of 'Stick Man' from a story the class were reading. Again data from field notes and video identify cues that children associate with play (Howard and McInnes, 2010; 2013), despite the session being a teacher directed activity. 'The children are all in wet weather gear and head off in pairs and small groups to collect sticks, leaves, pine cones and acorns to make a picture, two are playing on logs like stepping stones jumping and stepping, the rest are all busy on task' (Field notes, p48 L9). Again the comments show how the playful nature of a task maintains pupils' engagement in the activity. Analysis of film footage of the session 
also highlights this as 'all pupils are engaged in the task, they run in many directions and collect items from all over the small area of woodland, some are sorting out the materials they have collected and others are making pictures. The staff are asking them about the things they have collected. Some of the children can identify pine cones and acorns' (Video 9). Again here it is evident that the adults are providing opportunities for pupils to learn in playful contexts (Pyle and Alaca, 2018) which ensures that there are high levels of pupil engagement in learning.

\section{Conclusion}

The findings reported in this paper support existing literature suggesting play is strongly associated with pupils' motivation and engagement in learning (Brock et al., 2009; Brooker and Edwards, 2010; Howard et al., 2002; Howard and McInnes, 2010, 2011; Moyles, 2010). It would seem that pupils' perceptions of a task as play or work can be highly influential on their motivation to engage in a task and Howard and McInnes's $(2010,2011,2013)$ work suggest that pupils make these judgements about the nature of a task based on a series of environmental and emotional cues. It is therefore important that teachers have a knowledge and understanding of these cues when planning learning tasks and environments for their pupils. If teachers are able to devise playful approaches in their practice pupils will perceive an activity as play or playful in nature and as such are likely to be more engaged in the task. Experiential learning approaches exhibit cues that children associate with play such as being physical, outdoors, and involving choice. Therefore by adopting approaches that are experiential and autonomy supportive teachers can develop a playful pedagogy that results in high levels of pupil engagement and, according to Leavres (1997), result in deeper learning. 
References:

Akey, T.M. (2006) 'School Context, Student Attitudes and Behavior, and Academic Achievement: An Exploratory Analysis', MDRC. Available at: http://www.mdrc.org/sites/default/files/full 519.pdf [accessed on 23/9/13)

Anderman, E.M. and Maehr, M.L. (1994) 'Motivation and schooling in the middle grades', Review of Educational Research, 64(2), pp. 287-309.

Anning, A. and Edwards, A. (1999) Promoting Children's Learning from Birth to Five. Buckingham: Open University Press.

Benware, C.A. and Deci, E.L. (1984) 'Quality of learning with an active versus passive motivational set', American Educational Research Journal, 21(4), pp. 755-765.

Brock, A., Dodds, S., Jarvis, P. and Olusoga, Y., (ed.)(2009) Perspectives on Play Learning for Life, Harlow: Pearson.

Brooker, L. and Edwards, S. (ed.) (2010) Engaging Play, Maidenhead: McGraw-Hill.

Caracelli, V.J. and Greene, J.C. (1993) 'Data analysis strategies for mixed-method evaluation designs', Educational Evaluation and Policy Analysis, 15(2), pp. 195207.

Csikszentmihalyi, M. and LeFevre, J. (1989) 'Optimal experience in work and leisure', Journal of Personality and Social Psychology, 56(5), pp. 815-822.

Csikszentmihalyi, M. and Nakamura, J. (1979) 'The concept of flow', in Csikszentmihalyi, M. and Nakamura, J. (ed.) Play and learning, New York: Gardener Press, pp. 257-274.

Cohen, L., Manion, L. and Morrison, K. (2011) Research methods in education, London: Routledge. ( $7^{\text {th }}$ Edn.)

DCELLS (2008) Framework for Children's Learning for 3 to 7-year-olds in Wales, Cardiff: Welsh Assembly Government.

DCELLS (2015) Framework for Children's Learning for 3 to 7-year-olds in Wales, (Revised) Cardiff: Welsh Assembly Government.

Deci, E.L. and Ryan, R.M. (1985) Intrinsic motivation and self-determination in human behavior, New York and London: Plenum .

Deci, E.L., Vallerand, R.J., Pelletier, L.G. and Ryan, R.M. (1991) 'Motivation and Education: The Self-Determination Perspective,' Educational Psychologist, 26(3), pp. 325-346.

Deci, E.L., Eghrari, H., Patrick, B.C. and Leone, D.R. (1994) 'Facilitating internalization: The self-determination theory perspective', Journal of Personality, 62(1), pp. 119-142.

Dewey, J. (1933) How We Think, Boston, MA: D.C. Heath and Company.

Dewey, J. (1938) Experience and education, New York: Simon and Schuster.

Epstein, A. S. (2013) All about Highscope - FAQs. http://www.highscope.org/Content.asp?ContentId=291

Feezell, R. (2013) ‘A pluraslist conception of play', in Ryall, E., Russell, W. and MacLean, M. The Philosophy of Play, London: Routledge, pp. 11-31.

Fiskum, T.A. and Jacobsen, K. (2013) 'Outdoor education gives fewer demands for action regulation and an increased variability of affordances', Journal of Adventure Education and Outdoor Learning, 13(1), pp. 76-99.

Fjørtoft, I. (2001) 'The natural environment as a playground for children: The impact of outdoor play activities in pre-primary school children', Early Childhood Education Journal, 29(2), pp. 111-117.

Fleer, M. (2015) Pedagogical positioning in play - teachers being 
inside and outside of children's imaginary play, Early Child Development and Care, 185:11-12, pp. 1801-1814

Gibson, J.J. (1986) The ecological approach to visual perception, Hillsdale, NJ: Lawrence Erlbaum.

Glaser, B.G. and Strauss, A.L. (1967) The Discovery of Grounded Theory, Chicago, IL: Aldane.

Gottfried, A.E., Fleming, J.S. and Gottfried, A.W. (2001) 'Continuity of academic intrinsic motivation from childhood through late adolescence: A longitudinal study', Journal of educational psychology, 93(1), pp. 3-13.

Greene, J.C., Caracelli, V.J. and Graham, W.F. (1989) 'Toward a conceptual framework for mixed-method evaluation designs', Educational Evaluation and Policy Analysis, 11(3), pp. 255-274.

Harmer, A.J., \& Cates, W.M. (2004).Designing for learner engagement in middle school science: Technology, inquiry, and the hierarchies of engagement. Bethlehem, PA: Lehigh University.

Hastie, P.A., Rudisill, M.E. and Wadsworth, D.D. (2013) 'Providing students with voice and choice: lessons from intervention research on autonomy supportive climates in physical education', Sport, Education and Society, 18(1), pp. 38-56.

Hohmann, M., Weikart, D.P. and Epstein, A.S. (2002) Educating young children: second edition, Ypsilanti, MI: High/Scope Press.

Howard, J. (2002) 'Eliciting young children's perceptions of play, work and learning using the activity apperception story procedure', Early Child Development and Care, 172(5), pp. 489-502.

Howard, J. and McInnes, K. (2010) 'Thinking Through the Challenge of a play-based curriculum, increasing playfulness via co-construction', in Moyles, J.R. (ed.) Thinking about play, Berkshire: Open University Press.

Howard, J. and McInnes, K. (2013) The Essence of Play. A practice companion for professionals working with children and young people. Oxon: Routledge.

Howard, J., Bellin, W. and Rees, V. (2002) 'Eliciting children's perceptions of play and exploiting playfulness to maximise learning in the early years classroom', Annual Conference of the British Educational Research Association, University of Exeter, England, pp. 2-14.

Kyttä, M. (2002) 'Affordances of children's environments in the context of cities, small towns, suburbs and rural villages in Finland and Belarus', Journal of Environmental Psychology, 22(1), pp. 109-123.

Laevers, F. (1993) 'Deep level learning: an exemplary application on the area of physical knowledge', European Early Childhood Research Journal, Vol. 1, pp. 53-68.

Laevers, F., Moons, J., Daems, M., Debruyckere, G., Declercq, B., Silkens, K. and Snoeck, G. (2005) Sics [Ziko] Well-being and involvement in care-a processoriented self-evaluation instrument for care settings.

Laevers, F. (1997) "Assessing the quality of childcare provision: "Involvement" as criterion', Researching Early Childhood, vol. 3, pp. 151-165.

Laevers, F. and Declercq, B. (2011) Raising levels of well-being and involvement in Milton Keynes Preschool Settings.

Laevers, F. (2011) 'Experiential Education: Making care and education more effective through well-being and involvement', Encyclopedia on Early Childhood Development, pp. 1-5. 
Laevers, F. (2005) 'The curriculum as means to raise the quality of early childhood education. Implications for policy', European Early Childhood Education Research Journal, 13(1), pp. 17-29.

Laevers, F. (2000) 'Forward to Basics! Deep-Level-Learning and the Experiential Approach', Early years, 20(2), pp. 20-29.

Laevers, F. (1998) 'Understanding the world of objects and of people: Intuition as the core element of deep level learning', International Journal of Educational Research, 29(1), pp. 69-86.

Laevers, F. (1994a) 'The innovative project Experiential Education and the definition of quality in education', in Laevers, F. (ed.) Defining and assessing quality in early childhood education, pp. 159-172.

Laevers, F. (1994b) The Leuven Involvement Scale for Young Children. Oxford: Gecko publishing.

Laevers F, Declercq B, Thomas F. Leuven, Belgium: CEGO Leuven University; (2010) Implementation of the process-oriented approach in early years settings in Milton Keynes. Final report. Leuven, Belgium: CEGO Leuven University; 2010. Marks, H.M. (2000). Student engagement in instructional activity: Patterns in the elementary, middle and high school years. American Educational Research Journal, Vol. 37(1) pp. 153-184.

Maykut, P. and Morehouse, R. (1994) Beginning Qualitative Research: A Philosophic and Practical Guide, London: Routledge/Falmer.

Maynard, T., Waters, J. and Clement, J. (2011) 'Moving outdoors: further explorations of 'child-initiated' learning in the outdoor environment', Education 3-13, 41(3), pp. 282-299.

McInnes, K., Howard, J., Miles, G. and Crowley, K. (2010) 'Differences in adult-child interactions during playful and formal practice conditions: An initial investigation', Psychology of Education Review, 34(1), pp. 14-20.

McInnes, K., J. Howard, J., Miles, G. and K. Crowley, K. (2009) 'Behavioural differences exhibited by children when practising a task under formal and playful conditions', Educational and Child Psychology, 26(2), pp. 31-9.

McInnes, K., Howard, J., Miles, G. and Crowley, K. (2011) 'Differences in practitioners' understanding of play and how this influences pedagogy and children's perceptions of play', Early Years, 31(2), pp. 121-133.

Moyles, J. (2010) The excellence of play, New York: McGraw-Hill International.

Moyles, J.R. (1989) Just playing? The role and status of play in early childhood education, Milton Keynes: Open University Press.

Nakamura, J. and Csikszentmihalyi, M. (2002) 'The concept of flow', in Snyder, C.R. and Lopez, S.J. (ed.) Handbook of positive psychology, New York: Oxford University Press, pp. 89-105.

Niemiec, C.P. and Ryan, R.M. (2009) 'Applying self-determination theory to educational practice,' Theory and Research in Education, 7(2), pp. 133-144.

Newmann, F.M. (1992), Student Engagement and Achievement in American Secondary Schools, New York: Teachers College Press.

Opdenakker, M-C., Maulana, R. and den Brok, P. (2012), Teacher-student interpersonal relationshios and academic motivation within one school year: developmental changes and linkage. School Effectiveness and School Improvement, 23(1) pp. 95119.

Papatheodorou, T. (2010) 'The pedagogy of play(ful) learning environments' in Moyles, J.R. (ed.) Thinking about play, Maidenhead: Open University Press/McGraw-Hill Education, pp. 145-163. 
Papatheodorou, T. and Ramasut, A. (1994) 'Environmental effects on teachers' perceptions of behaviour problems in nursery school children', European Early Childhood Education Research Journal, 2(2), pp. 63-78.

Pascal, C., Bertram, T., Mould, C. and Hall, R. (1998) 'Exploring the relationship between process and outcome in young children's learning: stage one of a longitudinal study', International Journal of Educational Research, 29(1), pp. 5167.

Pascal, E. and Bertram, T. (1995) "'Involvement" and the Effective Early Learning Project: a collaborative venture, An exploration of the concept of" involvement" as an indicator of the quality of Early Childhood Care and Education'. Dundee: CIDREE Report, vol. 10, pp. 25-38.

Pellegrini, A.D. (1991) Applied child study, Hillsdale, NJ: Lawrence Erlbaum.

Penrose, V., Thomas, G. and Greed, C. (2001) 'Designing inclusive schools: how can children be involved?' Support for Learning, 16(2), pp. 87-91.

Pyle, A and Alaca, B. (2018) Kindergarten children's perspectives on play and learning, Early Child Development and Care, 188:8, pp. 1063-1075,

Pyle, A., and Daniels, E., (2017) A Continuum of Play-Based Learning: The Role of the Teacher in Play-Based Pedagogy and the Fear of Hijacking Play. Early Education and Development Vol.28(3) pp. 271-289

Reeve, J. (2006) 'Teachers as facilitators: What autonomy-supportive teachers do and why their students benefit', The Elementary School Journal, 106(3), pp. 225-236.

Reeve, J. and Jang, H. (2006) 'What teachers say and do to support students' autonomy during a learning activity', Journal of Educational Psychology, 98(1), pp. 209-218.

Reeve, J. Jang, H. Carrell, D. Barch, J. and Jeon, S. (2004) 'Enhancing students' engagement by increasing teachers' autonomy support', Motivation and Emotion vol. 28, pp. 147-169.

Ryan, R.M. and Deci, E.L. (2000) 'Intrinsic and extrinsic motivations: Classic definitions and new directions', Contemporary Educational Psychology, 25(1), pp. 54-67.

Ryan, R.M. and Grolnick, W.S. (1986) 'Origins and pawns in the classroom: Self-report and projective assessments of individual differences in children's perceptions', Journal of Personality and Social Psychology, 50(3), pp. 550-558.

Spradley, J. P. (1980) Participant Observation, Belmont, USA: Wadsworth.

Taylor, J., and L. Nelms. 2006.School engagement and life chances: 15 year olds in transition. Life Chances Study stage 7: Fitzroy, Vic: Brotherhood of St Lawrence.

Teddlie, C. and Tashakkori, A. (2009) Foundations of mixed methods research: Integrating quantitative and qualitative approaches in the social and behavioral sciences, Thousand Oaks, CA: Sage Publications Inc.

Wainwright, N., Goodway, J., Whitehead, M., Williams, A. and Kirk, D. (2016) The Foundation Phase in Wales - A play-based curriculum that supports the development of physical literacy. Education 3-13, Vol 44(5), 513-524

Wood, E. and Attfield, J. (2005) Play, learning and the early childhood curriculum. London: Sage. 